\title{
Influence of Agronomic Bio-fortification of Zinc and Iron on Their Density in Maize Grain and Nutrients Uptake
}

\author{
Nikhil kumar and SR Salakinkop* \\ Main Agriculture Research Station, University of Agricultural Sciences, India
}

Submission: November 30, 2017; Published: December 11, 2017

*Corresponding author: SR Salakinkop, Main Agriculture Research Station, University of Agricultural Sciences, Dharwad - 580 005, Karnataka, India, Email: salakinkopsr@uasd.in

\begin{abstract}
A field experiment on agronomic bio fortification of zinc and iron micronutrients in maize was carried out during kharif season of 2015 at Agricultural Research Station, Bail hongal. The experiment laid out in randomized block design with factorial concept with three replications consisted of 16 treatment combinations involving seed treatment (no seed treatment and seed treatment with Zn and Fe each @ 1 \%), soil application of $\mathrm{Zn}$ and $\mathrm{Fe}$ (no soil application, soil application of recommended $\mathrm{ZnSO}_{4}$ and $\mathrm{FeSO}_{4}$ each @ $25 \mathrm{~kg} \mathrm{ha}^{-1}$ and $\mathrm{FYM}^{-}$enriched $\mathrm{ZnSO}_{4}$ and $\mathrm{FeSO}_{4}$ application each @ $15 \mathrm{~kg} \mathrm{ha}^{-1}$ and FYM enriched $\mathrm{ZnSO}_{4}$ and $\mathrm{FeSO}_{4}$ application each @ $25 \mathrm{~kg} \mathrm{ha}^{-1}$ ) and foliar application of $\mathrm{Zn}$ and Fe at 45 DAS (no foliar and foliar spray of $\mathrm{ZnSO}_{4}$ and $\mathrm{FeSO}_{4}$ each @ $0.5 \%$ ). Significantly higher Zn (47 mg kg-1) and Fe $\left(75.2 \mathrm{mg} \mathrm{kg}^{-1}\right)$ density in maize grain was recorded with soil application of FYM enriched $\mathrm{ZnSO}_{4}$ and $\mathrm{FeSO}_{4}$ each @ $25 \mathrm{~kg} \mathrm{ha}^{-1}$ than control. And it was on par with the soil application of FYM enriched $\mathrm{ZnSO}_{4}$ and $\mathrm{FeSO}_{4}$ each @ $15 \mathrm{~kg} \mathrm{ha}^{-1}$.

Similarly higher foliar application of $\mathrm{ZnSO}_{4}$ and $\mathrm{FeSO}_{4}$ each @ 0.5 per cent accounted significantly higher zinc and iron content in grain (44.82

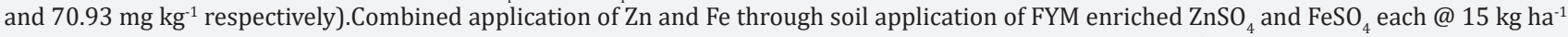
and foliar application without seed treatment $\left(\mathrm{T}_{1} \mathrm{~S}_{3} \mathrm{~F}_{2}\right)$ recorded higher $\mathrm{Zn}$ concentration in grain $\left(48.57 \mathrm{~g} \mathrm{~kg}^{-1}\right)$.Whereas, combined application of $\mathrm{Zn}$ and Fe through soil application of FYM enriched $\mathrm{ZnSO}^{4}$ and $\mathrm{FeSO}^{4}$ each @ $25 \mathrm{~kg} \mathrm{ha}^{-1}$ and foliar application without seed treatment $\left(\mathrm{T}_{1} \mathrm{~S}_{4} \mathrm{~F}_{2}\right)$ recorded higher Fe concentration in grain $\left(75.81 \mathrm{~g} \mathrm{~kg}^{-1}\right)$ compared to treatment consisting of no seed, soil and foliar spray.
\end{abstract}

\section{Introduction}

Maize (Zea mays L.) is the third most important cereal crop next to wheat and rice in the world as well as in India. In India maize is cultivated on $9.4 \mathrm{~m}$ ha with production of $2.3 \mathrm{~m}$ tonnes and productivity of 2.55 tonnes $\mathrm{ha}^{-1}$. In Karnataka it is being grown on an area of $1.36 \mathrm{~m}$ ha with production of $4.4 \mathrm{~m}$ tonnes and the productivity of $3.5 \mathrm{t} \mathrm{ha}^{-1}$ [1]. About half of the world's population suffers from micronutrient malnutrition, including iron, zinc and iodine which are mainly associated with low dietary intake of micronutrients in diets with less diversity of food [2,3]. Recent reports indicate that nearly 500,000 children under 5 years of age die annually because of $\mathrm{Zn}$ and Fe deficiencies [4]. Zinc deficiency in humans is widely noticed since zinc is an essential micronutrient for every living organism. In humans, zinc deficiency can lead to stunted growth, poor immune system, and, in children under five, impaired physical and neural development, leading to decreased brain functions that will remain up to adulthood. Iron deficiency is the most common cause of anemia globally. According to a recent report based on the WHO database, anemia affects nearly 1.6 billion people, and pre-school children and pregnant women are under great risk of Fe deficiency anemia [5].

\section{Materials and Methods}

The field experiment was conducted at Agricultural Research Station (ARS), Bailhongal, Belagavi District, and Karnataka during kharif season of 2015 which is situated in Northern Transitional Zone of Karnataka and located between 150.81' North latitude and 740.86 ' East longitudes with an altitude of $546 \mathrm{~m}$ above mean sea level. The soil of the experimental site is medium black in nature and the texture of the soil is clayey, belonging to the order vertisols. Composite soil sample were drawn from 0 to $15 \mathrm{~cm}$ depth from the experimental site before sowing and was analysed for physical and chemical properties. Clayey in texture $(10.65 \%$ sand, $30.0 \%$ silt, $59.12 \%$ clay), pH 7.3, E.C 0.34 ,low in organic carbon ( $4.8 \mathrm{~g} \mathrm{~kg}$ ${ }^{1}$ ), available nitrogen (218.4 $\mathrm{kg} \mathrm{ha}^{-1}$ ), available phosphorus (36.4 kg ha $^{-1}$ ) available potassium (347.2 $\mathrm{kg} \mathrm{ha}^{-1}$ ) available zinc (0.76 ppm) and available iron (4.19 ppm). Recommended dose of fertilizer (RDF-100:50:25 N: $\mathrm{P}_{2} \mathrm{O}_{5} \mathrm{~K}_{2} \mathrm{O} \mathrm{kg} \mathrm{ha}^{-1}+7.5 \mathrm{t} \mathrm{ha}^{-1} \mathrm{FYM}$ ) was applied to soil before sowing. The experiment was laid out in Randomized 
Complete Block Design (factorial concept) with 16 treatment combinations. Treatment combinations involving seed treatment, no seed treatment $\left(\mathrm{T}_{1}\right)$ and seed treatment with $\mathrm{Zn}$ and $\mathrm{Fe}$ each @1 \% ( $\left.\mathrm{T}_{2}\right)$, soil application of $\mathrm{Zn}$ and Fe i.e.no soil application $\left(\mathrm{S}_{1}\right)$, soil application of recommended $\mathrm{ZnSO}_{4}$ and $\mathrm{FeSO}^{4}$ each @ $25 \mathrm{~kg}$

Table 1: Zinc and iron content $\left(\mathrm{g} \mathrm{kg}^{-1}\right)$ in maize grain after harvest of the crop as influenced by seed, soil and foliar application of zinc and iron.

\begin{tabular}{|c|c|c|c|}
\hline & $\begin{array}{c}\text { Zinc } \\
\left(\mathrm{g} \mathrm{kg}^{-1}\right)\end{array}$ & $\begin{array}{c}\text { Iron } \\
\left(\mathrm{g} \mathrm{kg}^{-1}\right)\end{array}$ & $\begin{array}{c}\text { Grain yield } \\
\text { (q ha-1) }^{-1}\end{array}$ \\
\hline \multicolumn{4}{|c|}{ Factor I : Seed treatment } \\
\hline $\mathrm{T}_{1}$ :No seed treatment with $\mathrm{Zn}$ and Fe & $42.64^{\text {a }}$ & $68.56^{a}$ & $69.70^{\text {a }}$ \\
\hline $\mathrm{T}_{2}:$ Seed treatment with $\mathrm{Zn}$ and $\mathrm{Fe}$ & $44.32^{\mathrm{a}}$ & $68.87^{\mathrm{a}}$ & $71.17^{\text {a }}$ \\
\hline S.Em \pm & 0.77 & 0.29 & 1.55 \\
\hline \multicolumn{4}{|c|}{ Factor II : Soil application } \\
\hline $\mathrm{S}_{1}$ :Control (No application of $\mathrm{Zn}$ and $\mathrm{Fe}$ ) & $38.33^{\mathrm{b}}$ & $57.34^{\mathrm{c}}$ & $61.11^{\mathrm{b}}$ \\
\hline $\mathrm{S}_{2}$ : Soil application of recommended $\mathrm{ZnSO}^{4}$ and $\mathrm{FeSO}_{4}$ each @ $25 \mathrm{~kg} \mathrm{ha}^{-1}$ & $42.31^{\mathrm{ab}}$ & $68.11^{\mathrm{b}}$ & $69.42^{\mathrm{ab}}$ \\
\hline $\mathrm{S}_{3}:$ FYM enriched $\mathrm{ZnSO}^{4}$ and $\mathrm{FeSO}^{4}$ application each @ $15 \mathrm{~kg} \mathrm{ha}^{-1}$ & $46.29^{\mathrm{ab}}$ & $74.27^{\mathrm{a}}$ & $75.02^{\mathrm{ab}}$ \\
\hline $\mathrm{S}_{4}:$ FYM enriched $\mathrm{ZnSO}^{4}$ and $\mathrm{FeSO}^{4}$ application each @ $25 \mathrm{~kg} \mathrm{ha}^{-1}$ & $47.00^{\mathrm{a}}$ & $75.15^{\mathrm{a}}$ & $76.18^{\mathrm{a}}$ \\
\hline S.Em \pm & 1.09 & 0.41 & 2.19 \\
\hline \multicolumn{4}{|c|}{ Factor III :Foliar spray } \\
\hline $\mathrm{F}_{1}$ : No foliar application of $\mathrm{Zn}$ and Fe & $42.14^{\mathrm{b}}$ & $66.51^{\mathrm{b}}$ & $68.03^{\mathrm{b}}$ \\
\hline $\mathrm{F}_{2}$ : Foliar application of ZnSO4 and FeSO4 each @ $0.5 \%$ & $44.82^{\mathrm{a}}$ & $70.93^{\mathrm{a}}$ & $72.83^{\mathrm{a}}$ \\
\hline S.Em \pm & 0.77 & 0.29 & 1.55 \\
\hline \multicolumn{4}{|c|}{ Interaction } \\
\hline $\mathrm{T}_{1} \mathrm{~S}_{1} \mathrm{~F}_{1}$ & $36.59^{d}$ & $55.18^{\mathrm{e}}$ & $59.72^{\mathrm{d}}$ \\
\hline $\mathrm{T}_{1} \mathrm{~S}_{1} \mathrm{~F}_{2}$ & $37.97^{\mathrm{cd}}$ & $59.02^{\mathrm{d}}$ & $61.11^{\mathrm{cd}}$ \\
\hline $\mathrm{T}_{1} \mathrm{~S}_{2} \mathrm{~F}_{1}$ & $40.27^{\mathrm{b}-\mathrm{d}}$ & $63.16^{c}$ & $66.25^{\mathrm{a}-\mathrm{d}}$ \\
\hline $\mathrm{T}_{1} \mathrm{~S}_{2} \mathrm{~F}_{2}$ & $43.17^{\mathrm{a}-\mathrm{d}}$ & $72.74^{\mathrm{b}}$ & $69.39^{\mathrm{a}-\mathrm{d}}$ \\
\hline $\mathrm{T}_{1} \mathrm{~S}_{3} \mathrm{~F}_{1}$ & $41.63^{\mathrm{a}-\mathrm{d}}$ & $72.47^{\mathrm{b}}$ & $71.53^{\text {a-d }}$ \\
\hline $\mathrm{T}_{1} \mathrm{~S}_{3} \mathrm{~F}_{2}$ & $48.57^{a}$ & $75.54^{\mathrm{a}}$ & $77.64^{\mathrm{ab}}$ \\
\hline $\mathrm{T}_{1} \mathrm{~S}_{4} \mathrm{~F}_{1}$ & $45.47^{\mathrm{ab}}$ & $74.57^{\mathrm{a}}$ & $73.61^{\mathrm{a}-\mathrm{d}}$ \\
\hline $\mathrm{T}_{1} \mathrm{~S}_{4} \mathrm{~F}_{2}$ & $47.43^{\mathrm{ab}}$ & $75.81^{\mathrm{ab}}$ & $78.36^{\mathrm{a}}$ \\
\hline $\mathrm{T}_{2} \mathrm{~S}_{1} \mathrm{~F}_{1}$ & $38.23^{\mathrm{cd}}$ & $54.76^{\mathrm{e}}$ & $60.62^{\mathrm{d}}$ \\
\hline $\mathrm{T}_{2} \mathrm{~S}_{1} \mathrm{~F}_{2}$ & $40.53^{\mathrm{b}-\mathrm{d}}$ & $60.40^{\mathrm{d}}$ & $62.97^{\mathrm{b}-\mathrm{d}}$ \\
\hline $\mathrm{T}_{2} \mathrm{~S}_{2} \mathrm{~F}_{1}$ & $41.83^{\mathrm{a}-\mathrm{d}}$ & $63.91^{\mathrm{c}}$ & $66.36^{a-d}$ \\
\hline $\mathrm{T}_{2} \mathrm{~S}_{2} \mathrm{~F}_{2}$ & $43.97^{\mathrm{a}-\mathrm{c}}$ & $72.61^{\mathrm{b}}$ & $75.69^{\mathrm{a}-\mathrm{c}}$ \\
\hline $\mathrm{T}_{2} \mathrm{~S}_{3} \mathrm{~F}_{1}$ & $46.47^{\mathrm{ab}}$ & $73.32^{\mathrm{ab}}$ & $72.44^{\mathrm{a}-\mathrm{d}}$ \\
\hline $\mathrm{T}_{2} \mathrm{~S}_{3} \mathrm{~F}_{2}$ & $48.48^{\mathrm{a}}$ & $75.75^{\mathrm{a}}$ & $78.47^{\mathrm{a}}$ \\
\hline $\mathrm{T}_{2} \mathrm{~S}_{4} \mathrm{~F}_{1}$ & $46.67^{\mathrm{ab}}$ & $74.69^{\mathrm{ab}}$ & $73.73^{a-d}$ \\
\hline $\mathrm{T}_{2} \mathrm{~S}_{4} \mathrm{~F}_{2}$ & $48.42^{\mathrm{a}}$ & $75.53^{\mathrm{a}}$ & $79.03^{a}$ \\
\hline S.Em \pm & 2.18 & 0.82 & 4.39 \\
\hline
\end{tabular}

Means followed by same letters in the column do not differ significantly by DMRT $(p=0.05)$

\section{Results and Discussion}

Zinc and iron content in grain after harvest of crop increased significantly due to soil application of different levels of $\mathrm{Zn}$ and Fe. There was increase in grain concentration of $\mathrm{Zn}$ and Fe from 38.83 to 47 and 57.59 to $75.23 \mathrm{mg} \mathrm{kg}^{-1}$ respectively. Application of FYM enriched $\mathrm{ZnSO}_{4}$ and $\mathrm{FeSO}_{4}$ each @25 kg ha-1 (47 g kg-1),

ha $^{-1}\left(\mathrm{~S}_{2}\right)$, FYM enriched $\mathrm{ZnSO}_{4}$ and $\mathrm{FeSO}_{4}$ application each @ $15 \mathrm{~kg}$ ha $^{-1}\left(\mathrm{~S}_{3}\right)$ and FYM enriched $\mathrm{ZnSO}_{4}$ and $\mathrm{FeSO}_{4}$ application each @ $25 \mathrm{~kg} \mathrm{ha}^{-1}\left(\mathrm{~S}_{4}\right)$ and foliar application of $\mathrm{Zn}$ and Fe i.e. no foliar $\left(\mathrm{F}_{1}\right)$ and foliar spray of $\mathrm{ZnSO}_{4}$ and $\mathrm{FeSO}_{4}$ each @ $0.5 \%\left(\mathrm{~F}^{2}\right)$ at 45 DAS

$\left(\mathrm{g} \mathrm{kg}^{-1}\right)$

$\left(\mathrm{g} \mathrm{kg}^{-1}\right)$

(a)

$\left(q\right.$ ha-1 $\left.^{-1}\right)$

n 
$\mathrm{kg} \mathrm{ha}^{-1}$ (894.66 $\mathrm{g} \mathrm{ha}^{-1}$ ) over no soil application (655.35 g ha $\left.{ }^{1}\right)$. Similar results were reported $[6,7]$. In none of of treatments density of these two essential heavy metals did exceeded the normal concentration found in plant system. The optimum concentration range of $\mathrm{Zn}$ and $\mathrm{Fe}$ in plants is $26-150 \mathrm{ppm}$ and 50 - 150 respectively.

Similarly application of FYM enriched $\mathrm{ZnSO}_{4}$ and $\mathrm{FeSO}_{4}$ each @25 kg ha-1 $\left(75.15 \mathrm{~g} \mathrm{~kg}^{-1}\right)$, FYM enriched $\mathrm{ZnSO}_{4}$ and $\mathrm{FeSO}_{4}$ each @15 $\mathrm{kg} \mathrm{ha}^{-1}\left(74.27 \mathrm{~g} \mathrm{~kg}^{-1}\right)$ and straight application of recommended $\mathrm{ZnSO}_{4}$ and $\mathrm{FeSO}_{4}$ each @25 kg ha-1 $\left(68.11 \mathrm{~g} \mathrm{~kg}^{-1}\right)$ increased the iron content in grain by 23.6, 22.7 and 15.8 per cent respectively over control (57.34 $\mathrm{g} \mathrm{kg}^{-1}$ ) and they were on par with each other. The results were in accordance with the finding [8]. The reason could be enrichment of FYM with zinc and iron which regulates its supply to the crop by slowly releasing of the nutrients into soil solution would have facilitated the higher nutrient uptake. And further enrichment of nutrients with organics prevents them from leaching and other losses [9]. The higher Fe uptake by maize crop was observed with soil application of FYM enriched $\mathrm{ZnSO} 4$ and $\mathrm{FeSO}_{4}$ each @25 kg ha ${ }^{-1}$ (1098 $\mathrm{g} \mathrm{ha}^{-1}$ ) over control (578.29 $\mathrm{g} \mathrm{ha}^{-1}$ ). And it was on par with the application of FYM enriched $\mathrm{Zn}$ and Fe each @15 kg ha-1. Foliar application of $\mathrm{ZnSO}_{4}$ and $\mathrm{FeSO}_{4}$ each @ 0.5 per cent accounted significantly higher zinc and iron content in grain (44.82 and $70.93 \mathrm{mg} \mathrm{kg}^{-1}$ respectively) overno foliar application of $\mathrm{Zn}$ and Fe (42.14 and $66.51 \mathrm{mg} \mathrm{kg}^{-1}$ respectively). Foliar application of $\mathrm{ZnSO}_{4}$ and $\mathrm{FeSO}_{4}$ each @ 0.5 per cent recorded significantly higher $\mathrm{Zn}$ and Fe uptake by maize crop (840.25 and $947.96 \mathrm{~g} \mathrm{ha}^{-1}$ ) over no foliar application (773.66 and $862.21 \mathrm{~g}$ ha $\left.{ }^{1}\right)$. Similar observations were recorded [10] (Table 2).

Table 2: Nitrogen, phosphorus and potassium uptake by maize at harvest as influenced by seed, soil and foliar application of zinc and iron.

\begin{tabular}{|c|c|c|c|c|c|}
\hline & $\begin{array}{c}\mathrm{N} \\
\left(\mathrm{kg} \mathrm{ha}^{-1}\right)\end{array}$ & $\begin{array}{c}P \\
\left(\mathrm{~kg} \mathrm{ha}^{-1}\right)\end{array}$ & $\begin{array}{c}\mathrm{K} \\
\left(\mathrm{kg} \mathrm{ha}^{-1}\right)\end{array}$ & $\begin{array}{c}\mathrm{Zn} \\
\left(\mathrm{g} \mathrm{ha}^{-1}\right)\end{array}$ & $\begin{array}{c}\text { Fe } \\
\left(\mathrm{g} \mathrm{ha}^{-1}\right)\end{array}$ \\
\hline \multicolumn{6}{|c|}{ Factor I : Seed treatment } \\
\hline $\mathrm{T}_{1}$ : No seed treatment with $\mathrm{Zn}$ and Fe & $168.09^{a}$ & $35.09_{a}$ & $152.62_{\mathrm{a}}$ & $795.21_{\mathrm{a}}$ & $889.56_{a}$ \\
\hline $\mathrm{T}_{2}:$ Seed treatment with $\mathrm{Zn}$ and Fe & $172.56_{\mathrm{a}}$ & $35.12_{\mathrm{a}}$ & $153.47_{\mathrm{a}}$ & $818.69_{a}$ & $920.00 \mathrm{a}$ \\
\hline S.Em \pm & 2.37 & 0.46 & 1.12 & 11.97 & 12.27 \\
\hline \multicolumn{6}{|c|}{ Factor II : Soil application } \\
\hline $\mathrm{S}_{1}$ :Control (No application of $\mathrm{Zn}$ and $\mathrm{Fe}$ ) & $138.52^{\mathrm{b}}$ & $34.36^{\mathrm{a}}$ & $139.08^{\mathrm{b}}$ & $655.35^{\mathrm{b}}$ & $578.29^{c}$ \\
\hline $\begin{array}{l}\mathrm{S}_{2} \text { : Soil application of recommended } \mathrm{ZnSO}_{4} \text { and } \mathrm{FeSO}_{4} \text { each @ } 25 \mathrm{~kg} \\
\text { ha }^{-1}\end{array}$ & $163.28^{\mathrm{ab}}$ & $35.75^{\mathrm{a}}$ & $148.98^{\mathrm{ab}}$ & $786.46^{\mathrm{ab}}$ & $898.70^{\mathrm{b}}$ \\
\hline $\mathrm{S}_{3}:$ FYM enriched $\mathrm{ZnSO}_{4}$ and $\mathrm{FeSO}_{4}$ application each @ $15 \mathrm{~kg} \mathrm{ha}^{-1}$ & $187.87^{\mathrm{a}}$ & $35.52^{\mathrm{a}}$ & $161.39^{\mathrm{a}}$ & $891.35^{\mathrm{a}}$ & $1043.27^{\mathrm{ab}}$ \\
\hline $\mathrm{S}_{4}:$ FYM enriched $\mathrm{ZnSO}^{4}$ and $\mathrm{FeSO}^{4}$ application each @ $25 \mathrm{~kg} \mathrm{ha}^{-1}$ & $191.61^{\mathrm{a}}$ & $34.79^{\mathrm{a}}$ & $162.74^{\mathrm{a}}$ & $894.66^{a}$ & $1098.86^{\mathrm{a}}$ \\
\hline S.Em \pm & 3.36 & 0.66 & 1.58 & 16.93 & 17.36 \\
\hline \multicolumn{6}{|c|}{ Factor III: Foliar spray } \\
\hline $\mathrm{F}^{1}:$ No foliar application of $\mathrm{Zn}$ and $\mathrm{Fe}$ & $164.89^{\mathrm{b}}$ & $35.07^{\mathrm{a}}$ & $151.57^{\mathrm{a}}$ & $773.66^{\mathrm{b}}$ & $862.21^{\mathrm{b}}$ \\
\hline $\mathrm{F}^{2}$ : Foliar application of $\mathrm{ZnSO}_{4}$ and $\mathrm{FeSO}_{4}$ each @ $0.5 \%$ & $175.75^{\mathrm{a}}$ & $35.14^{\mathrm{a}}$ & $154.53^{\mathrm{a}}$ & $840.25^{\mathrm{a}}$ & $947.36^{\mathrm{a}}$ \\
\hline S.Em \pm & 2.37 & 0.46 & 1.12 & 11.97 & 12.27 \\
\hline \multicolumn{6}{|c|}{ Interaction } \\
\hline $\mathrm{T}_{1} \mathrm{~S}_{1} \mathrm{~F}_{1}$ & $136.07^{b}$ & $34.46 a$ & $137.62^{\mathrm{d}}$ & $607.05^{\mathrm{d}}$ & $548.39^{e}$ \\
\hline $\mathrm{T}_{1} \mathrm{~S}_{1} \mathrm{~F}_{2}$ & $140.63^{\mathrm{b}}$ & $34.60^{\mathrm{a}}$ & $139.32^{\mathrm{d}}$ & $697.85^{\mathrm{b}-\mathrm{d}}$ & $593.19^{e}$ \\
\hline $\mathrm{T}_{1} \mathrm{~S}_{2} \mathrm{~F}_{1}$ & $146.23^{\mathrm{b}}$ & $35.55^{\mathrm{a}}$ & $147.10^{\text {cd }}$ & $724.02^{\mathrm{b}}$ & $811.45^{\mathrm{d}}$ \\
\hline $\mathrm{T}_{1} \mathrm{~S}_{2} \mathrm{~F}_{2}$ & $175.53^{\mathrm{a}}$ & $35.73^{\mathrm{a}}$ & $151.82^{\mathrm{bc}}$ & $823.74^{a}$ & $941.25^{\mathrm{bc}}$ \\
\hline $\mathrm{T}_{1} \mathrm{~S}_{3} \mathrm{~F}_{1}$ & $174.08^{\mathrm{a}}$ & $36.05^{\mathrm{a}}$ & $158.91^{\mathrm{ab}}$ & $829.83^{a}$ & $989.27^{\mathrm{ab}}$ \\
\hline $\mathrm{T}_{1} \mathrm{~S}_{3} \mathrm{~F}_{2}$ & $192.33^{a}$ & $35.37^{\mathrm{a}}$ & $160.78^{\mathrm{ab}}$ & $916.76^{a}$ & $1072.17^{\mathrm{ab}}$ \\
\hline $\mathrm{T}_{1} \mathrm{~S}_{4} \mathrm{~F}_{1}$ & $188.98^{\mathrm{a}}$ & $34.65^{\mathrm{a}}$ & $162.28^{\mathrm{a}}$ & $882.08^{\mathrm{a}}$ & $1073.88^{a}$ \\
\hline $\mathrm{T}_{1} \mathrm{~S}_{4} \mathrm{~F}_{2}$ & $190.83^{\mathrm{a}}$ & $34.32^{\mathrm{a}}$ & $163.17^{\mathrm{a}}$ & $911.75^{a}$ & $1119.88^{\mathrm{a}}$ \\
\hline $\mathrm{T}_{2} \mathrm{~S}_{1} \mathrm{~F}_{1}$ & $138.71^{\mathrm{b}}$ & $33.46^{\mathrm{a}}$ & $138.93^{\mathrm{d}}$ & $615.22^{\mathrm{cd}}$ & $549.26^{\mathrm{e}}$ \\
\hline $\mathrm{T}_{2} \mathrm{~S}_{1} \mathrm{~F}_{2}$ & $138.67^{\mathrm{b}}$ & $34.93^{\mathrm{a}}$ & $140.44^{\mathrm{d}}$ & $701.28^{\mathrm{b}-\mathrm{d}}$ & $622.33^{e}$ \\
\hline $\mathrm{T}_{2} \mathrm{~S}_{2} \mathrm{~F}_{1}$ & $153.04^{\mathrm{b}}$ & $35.75^{\mathrm{a}}$ & $142.18^{\mathrm{d}}$ & $720.70^{\mathrm{bc}}$ & $834.39^{\text {cd }}$ \\
\hline $\mathrm{T}_{2} \mathrm{~S}_{2} \mathrm{~F}_{2}$ & $178.31^{\mathrm{a}}$ & $35.99^{a}$ & $154.81^{\mathrm{a}-\mathrm{c}}$ & $877.37^{a}$ & $1007.70^{\mathrm{ab}}$ \\
\hline $\mathrm{T}_{2} \mathrm{~S}_{3} \mathrm{~F}_{1}$ & $188.44^{\mathrm{a}}$ & $35.81^{\mathrm{a}}$ & $162.93^{\mathrm{a}}$ & $911.87^{\mathrm{a}}$ & $1025.17^{\mathrm{a}}$ \\
\hline $\mathrm{T}_{2} \mathrm{~S}_{3} \mathrm{~F}_{2}$ & $196.65^{a}$ & $34.86^{\mathrm{a}}$ & $162.94^{\mathrm{a}}$ & $924.73^{\mathrm{a}}$ & $1116.94^{\mathrm{a}}$ \\
\hline
\end{tabular}


International Journal of Environmental Sciences \& Natural Resources

\begin{tabular}{|c|c|c|c|c|c|}
\hline $\mathrm{T}_{2} \mathrm{~S}_{4}$ & $193.59^{\mathrm{a}}$ & $34.88^{\mathrm{a}}$ & $162.59^{\mathrm{a}}$ & $898.50^{\mathrm{a}}$ & $1065.84^{\mathrm{a}}$ \\
\hline $\mathrm{T}_{2} \mathrm{~S}_{4} \mathrm{~F}_{2}$ & $193.04^{\mathrm{a}}$ & $35.34^{\mathrm{a}}$ & $162.93^{\mathrm{a}}$ & $899.85^{\mathrm{a}}$ & $1138.37^{\mathrm{a}}$ \\
\hline $\mathrm{S} . \mathrm{Em} \pm$ & 6.71 & 1.33 & 3.17 & 33.87 & 34.71 \\
\hline
\end{tabular}

Means followed by same letters in the column do not differ significantly by DMRT $(p=0.05)$

$\mathrm{Zn}$ and Fe were directly absorbed by leaves and finally accumulated into grain [11]. Foliar application of $\mathrm{ZnSO}_{4}$ and $\mathrm{FeSO}_{4}$ each @0.5 per cent at 45 DAS facilitates much better translocation of applied nutrients into the developing grains [12]. Combined application of $\mathrm{Zn}$ and Fe through seed, soil and foliar application recorded significantly higher $\mathrm{Zn}$ and Fe density in the maize grain. There was increase in grain concentration of $\mathrm{Zn}$ and $\mathrm{Fe}$ from 36.59 to 48.57 and 55.18 to $75.81 \mathrm{mg} \mathrm{kg}^{-1}$ respectively. Combined application of $\mathrm{Zn}$ and Fe through soil application of FYM enriched $\mathrm{ZnSO}_{4}$ and $\mathrm{FeSO}_{4}$ each @15 kg ha-1 and foliar application but without seed treatment (T1S3F2) increased the Zn concentration in grain ( $48.57 \mathrm{~g} \mathrm{~kg}^{-1}$ ) by 24.3 per cent over devoid ofseed, soil and foliar application of $\mathrm{Zn}$ and Fe (36.59 $\mathrm{g} \mathrm{kg}^{-1}$ ). Similarly, combined application of $\mathrm{Zn}$ and Fe through soil application of FYM enriched $\mathrm{ZnSO}_{4}$ and $\mathrm{FeSO}_{4}$ each @25 kg ha ${ }^{-1}$ and foliar application but without seed treatment $\left(\mathrm{T}_{1} \mathrm{~S}_{4} \mathrm{~F}_{2}\right)$ increased the Fe concentration in grain $\left(75.81 \mathrm{~g} \mathrm{~kg}^{-1}\right)$ by 27.2 per cent over no seed, soil and foliar application of $\mathrm{Zn}$ and $\mathrm{Fe}\left(55.18 \mathrm{~g} \mathrm{~kg}^{-1}\right)$. Among the interactions treatment combination involving seed treatment, soil application of FYM enriched $\mathrm{ZnSO}_{4}$ and $\mathrm{FeSO}_{4}$ each @15 kg ha-1 and foliar application $\left(\mathrm{T}_{2} \mathrm{~S}_{4} \mathrm{~F}_{2}\right)$ recorded higher up take zinc (924.73 g ha ${ }^{1}$ ) and iron (1116.94 $\mathrm{g} \mathrm{ha}^{-1}$ ) compared to devoid of seed, soil and foliar application.

The application of FYM enriched $\mathrm{ZnSO}_{4}$ and $\mathrm{FeSO}_{4}$ each @25 $\mathrm{kg} \mathrm{ha}^{-1}$ recorded significantly higher uptake of $\mathrm{N}$ and $\mathrm{K}$ by maize crop at harvest (191.61 and $162.7 \mathrm{~kg} \mathrm{ha}^{-1}$ ) over no application of $\mathrm{Zn}$ and $\mathrm{Fe}$ (138.5 and $139.0 \mathrm{~kg} \mathrm{ha}^{-1}$ ). Foliar application of $\mathrm{ZnSO}_{4}$ and $\mathrm{FeSO}_{4}$ each @0.5 per cent accounted higher nitrogen and potassium uptake by maize (175.7 and $154.5 \mathrm{~kg} \mathrm{ha}^{-1}$ respectively) over no foliar application (164.8and $151.5 \mathrm{~kg} \mathrm{ha}^{-1}$ respectively). Among the interactions treatment combination involving seed treatment, soil application of FYM enriched $\mathrm{ZnSO}_{4}$ and $\mathrm{FeSO}_{4}$ each @15 kg ha-1 and foliar application $\left(\mathrm{T}_{2} \mathrm{~S}_{4} \mathrm{~F}_{2}\right)$ recorded higher uptake of nitrogen (196.6 $\mathrm{kg} \mathrm{ha}^{-1}$ ) and potassium (162.9 $\mathrm{kg} \mathrm{ha}^{-1}$ ). This could be due to synergetic effect between $\mathrm{Zn}$ and Fe with other nutrients. The similar observation was earlier recorded $[1,13]$.

The soil application of FYM enriched $\mathrm{ZnSO} 4$ and $\mathrm{FeSO}_{4}$ each @25 kg ha-1 recorded significantly lower available $\mathrm{N}$ and $\mathrm{K}$ in soil at harvest (204.2 and $291.6 \mathrm{~kg} \mathrm{ha}^{-1}$ ) over no application of $\mathrm{Zn}$ and Fe (211.5 and $313.1 \mathrm{~kg} \mathrm{ha}^{-1}$ ). Control recorded significantly higher available nitrogen and potassium in soil after harvest of maize as result of lower uptake of these nutrients in plants. The enrichment of FYM with $\mathrm{Zn}$ and Fe caused utilization of nutrients mainly due to its beneficial effect in mobilizing the native nutrients to increase their availability to crop uptake this could be the reason for less available $\mathrm{N}$ and $\mathrm{K}$ in the soil after harvest. Application of recommended $\mathrm{ZnSO}_{4}$ and $\mathrm{FeSO}_{4}$ each @25 kg ha-1 to the soil recorded significantly higher available $\mathrm{Zn}$ and Fe (1.12 and $7.75 \mathrm{ppm}$ respectively) over no application of Zn and Fe (0.61 and $4.40 \mathrm{ppm}$ respectively). Similar results were also observed by [3]. Treatment combination involving seed treatment, soil application of FYM enriched $\mathrm{Zn}$ and Fe and foliar application recorded significantly lower available nitrogen $\left(\mathrm{T}_{2} \mathrm{~S}_{4} \mathrm{~F}_{2}: 202.9 \mathrm{~kg}\right.$ $\left.\mathrm{ha}^{-1}\right)$ and potassium $\left(\mathrm{T}_{1} \mathrm{~S}_{4} \mathrm{~F}_{2}: 289.6 \mathrm{~kg} \mathrm{ha}^{-1}\right)$ compared to devoid of seed, soil and foliar application $\left(212.7 \mathrm{~kg} \mathrm{ha}^{-1}\right.$ and $314.8 \mathrm{~kg}^{-1}$ respectively). Availability of $\mathrm{Zn}$ and Fe in soil after harvest was the highest in combination involving seed treatment and application of recommended $\mathrm{ZnSO}_{4}$ and $\mathrm{FeSO}_{4}$ each @ $25 \mathrm{~kg} \mathrm{ha}^{-1}$ without foliar application $\left(\mathrm{T}_{2} \mathrm{~S}_{2} \mathrm{~F}_{1}: 1.16\right.$ and $\left.7.85 \mathrm{ppm}\right)$ compared to no seed soil and foliar application (0.6 and $4.41 \mathrm{ppm}$ ). Similar results found in maize.

\section{References}

1. Anonymous (2014) Agricultural Statistics at glance, Directorate of economics and statistics. Department of Agriculture and Co-operation, Ministry of Agriculture, Govt. Of India, India.

2. Brown KH, Wuehler SE, Peerson JM (2001) The importance of zinc in human nutrition and estimation of the global prevalence of zinc deficiency. Food Nutr Bull 22(1): 113-125.

3. Hotz C, Mc Clafferty B (2007) From Harvest to Health: Challenges for developing biofortified staple foods and determining their impact on micronutrient status. Food Nutr Bull 28(2): 271-279.

4. Black RE, Lindsay HA, Bhutta ZA, Caulfield LE, De Onnis M, et al. (2008) Maternal and child under nutrition: Global and regional exposures and health consequences. Lancet 371: 243-260.

5. Mc Leon E, Cogswell M, Egli I, Wojdyla D, de Benoist B (2009) Worldwide prevalence of anaemia, WHO Vitamin and Mineral Nutrition Information System. Public Health Nutr 12(4): 444-454.

6. Anuradha P, Adsul PB, Ganesh G, Ajeet P, Shaikh MS (2011) Influence of zinc and iron application on kharifsorghum. Bioinflet 11 (2): 572-574.

7. Rathod DD, Meena MC, Patel KP (2012) Effect of Different Zn-Enriched Organics on Yields and Micronutrient uptake under Wheat-Maize (Fodder) Cropping Sequence in Semi-Arid Region of Gujarat. Indian J Dryland Agric Res Dev 27(1): 37-42.

8. Basavaraj PK, Dasog R, Vijayakumar, Sarangamath PK (1995) Effect of zinc and iron application on maize yield in an irrigation vertisol. Karnataka J Agric Sci 8(1): 34-39.

9. Sharma A, Nakul HT, Jelgeri BR, Ashok Surwenshi (2001) Effect of micronutrients on growth, yield and yield components in pigeonpea (Cajanus Cajan L.Millsp.). Res J Agric Sci 1(2): 142-144.

10. Dhaliwal SS, Sadana US, Khurana MPS, Dhandli HS, Manchand JS (2010) Enrichment of rice grains with Zinc and Iron through ferti-fortification. Indian J Fertilizer 6(7): 28-35.

11. Slaton NA, Charles E, Wilson J, Ntamatungiro S, Richard J, et al. (2001) Evaluation of zinc seed treatments for rice. Agron J 93(1): 152-157.

12. Mufit K, Zafer A, Oguz O, cakmak I (2005) The effect of soil and foliar application of $\mathrm{Zn}$ on grain $\mathrm{Zn}$ concentration of wheat and maize. Archives Agron Soil Sci 53(3): 305-313. 
13. Pooniya V, Shivay YS (2011) Effect of green manuring and zinc fertilization on productivity and nutrient uptake in Basmati rice (Oryza sativa)-wheat (Triticumaestivum) cropping system. Indian J Agron 56(1): 28-34.

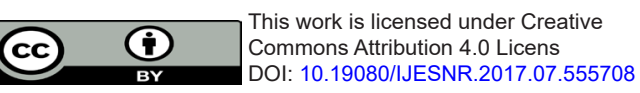

Your next submission with Juniper Publishers will reach you the below assets

- Quality Editorial service

- Swift Peer Review

- Reprints availability

- E-prints Service

- Manuscript Podcast for convenient understanding

- Global attainment for your research

- Manuscript accessibility in different formats

(Pdf, E-pub, Full Text, Audio)

- Unceasing customer service

Track the below URL for one-step submission https://juniperpublishers.com/online-submission.php 